\title{
Non-Performing Loan and How to Solve It
}

\author{
I Nyoman Alit Puspadma \\ Faculty of Law, Universitas Warmadewa, Denpasar, Bali-Indonesia \\ Email: alit.pus7@gmail.com
}

Published: 31/08/2021

How to cite:

Puspadma, I. N. A. 2021. Non-Performing Loan and How to Solve It. Sociological Jurisprudence Journal. Volume 4 Issue 2 . Page 145 - 152. https://doi.org/10.22225/scj.4.2.2021.145-152

\begin{abstract}
Credit delivery by the bank requires the debtor to pay the obligations that have been scheduled in the credit agreement, but it will not always work well, sometimes because of something and other things there are also debtors who can not fulfill the obligations that have been promised so that credit problems occur. Non-performing loans also cause problems for banks, because they can make banks collapse. Thus the question arises, how to avoid the occurrence of problem loans and if it occurs, how is the solution?.
\end{abstract}

Keywords: Credit; Problem; Method; Avoid; Settle.

\section{INTRODUCTION}

Day by day the population increasied. As the population grows, so do the living needs that must be fulfilled. The most basic necessities of life must be fulfilled are clothing, food, shelter, plus health and education.

The increase in the necessities of life that must be fulfilled causes the opening of business opportunities for people with an entrepreneurial spirit. Business opportunities that can arise from meeting the needs for clothing are opening a business in the field of convection, shoes, sandals, etc., to meet the needs in the food sector is to open a business / grocery store (nine staples), restaurants and others, meeting the needs in the field of boards (home) business opportunities are opening a property business, electricity shop, grocery store (household appliances) and others, fulfilling the needs in the health sector its business opportunities are opening a clinic, hospital, etc. -other, while for fulfilling the need for education business opportunity is by opening schools. All of these business opportunities require capital, without capital all businesses will not be able to run. Basically, capital is the main asset of a company to run a business which is usually in the form of money. With the money, all business will be smooth.

Capital in the form of money can be sourced from oneself or from other people or parties. By using one's own money, no responsibility is required to other parties as the loss will be borne by itself and the profit will be enjoyed by itself as well. It would be different if the money was obtained from other parties, either by way of cooperation or by means of a loan. Capital in the form of money sourced from loans will put more burden on an entrepreneur because he must be responsible to the lender regarding the money he borrowed. Loans can come from individuals or can also come from financial institutions such as banks.

The definition of bank according to the General Indonesian Dictionary, is a business entity in the financial sector that attracts and spends money in society, especially providing credit and services in the payment traffic and circulation of money. Thus the bank is a financial institution that can provide loans to the public. According to the American Bankers Association, banks have four main economic functions, namely:

a. The deposit function; 
b. The payment function;

c. The loan function, and

d. The money function (American Bankers Association, 1971).

According to Simorangkir, banks in providing credit, financing and other services are carried out with their own capital, or with funds entrusted by third parties or by distributing new payment instruments in the form of demand deposits (Simorangkir, 1989). Pursuant to Article 1 number 2 of Act No. 10 of 1998 concerning Amendment to Act No. 7 of 1992 concerning banking hereinafter referred to as Act 10/1998:

Bank is a business entity that collects funds from the public in the form of deposits and distributes them to the public in the form of credit and or other forms in order to improve the lives of many people..

Whereas the Rural Credit Bank according to Article 1 number 4 of Act 10/1998, is:

Rural Credit Bank is a bank that conducts business activities conventionally or based on Sharia Principles which in its activities do not provide services in payment traffic.

Pursuant to Article 1 number 4 of the Financial Services Authority Regulation number 62 / POJK.03 / 2016:

Bank Rural Credit Bank, hereinafter referred to as BPR, is a bank conducting conventional business activities which in its activities do not provide services in the payment traffic as referred to in Act Number 7 of 1992 concerning Banking as amended by Act Number 10 of 1998 concerning Amendment of Act Number 7 of 1992 concerning Banking.

Based on the aforementioned provisions, basically both banks (commercial banks) and BPR both run businesses in the context of collecting public funds in the form of deposits, to be distributed back to the public in the form of credit, but the difference is that commercial banks can provide services in payment traffic (issuing checks and demand deposits), whereas BPRs do not.

The business activities of commercial banks and rural banks (hereinafter referred to as banks) in providing credit to the public are very helpful for entrepreneurs/businessman to advance their businesses or to create new businesses in the context of business development. Assistance that can be provided by the Bank in the form of credit can be used to increase business capital.

Providing credit to the community, including entrepreneurs (debtors), is a risky business. The bank as the creditor has fulfilled the achievement in the form of giving an agreed amount of money in the credit agreement, while the customer as a new debtor will fulfill the achievement within the agreed period. Problems that arise if the debtor cannot fulfill his performance in accordance with the schedule agreed in the credit agreement, then there will be non-performing loan that can be detrimental to the Bank. The question that arises is: how to avoid the occurrence of problem loans and if it occurs, how is the solution?

\section{RESULT AND DISCUSSION}

\section{The Definiton of Non-Performing Credit}

According to As. Mahmoeddin: Non-performing loans are non-current loans or loans where the debtor cannot fulfill the agreed terms, for example interest payment requirements, loan principal collection, increased margin deposit, binding and increase of collateral, and so on (Mahmoeddin, 2004). Non-performing loans have been categorized by The Central Bank of Indonesia as determined in Article 4 of the Decree of the Board of Directors of The Central Bank of Indonesia number 31/147 / KEP / DIR dated November 12, 1998 concerning Quality of Productive Assets as follows:

Article 4

(1) Credit quality is classified as current credit, special attention, substandard, doubtful and NonPerformng according to the criteria determined as stated in the Attachment to this Decree.

(2) Attachments as set forth in paragraph (1) constitute an integral part of this

Pursuant to Article 4 paragraph (1) of the The Central Bank of Indonesia Decree, the credit quality category (collectibility) can be sorted as follows: 1) curent, 2) under special attention, 3) substandard, 4) 
doubtful, and 5) non-performing. Furthermore, it is described in more detail in the appendix to the decree, as follows::

1. Current credit is credit that does not experience a delay in repayment of loan principal and interest payments.

2. Special attention loans, are those that have delayed the principal repayment and/or interest payment for up to ninety days.

3. Sub-standard loans, are loans whose principal repayments and/or interest payments have been delayed for three months from the time agreed upon.

4. Doubtful loans, are loans whose principal repayments and/or interest payments have been delayed for six months or twice of the agreed schedule.

5. Non-Performing loans, are loans whose principal repayments and/or interest payments have been delayed more than one year since maturity according to the agreed schedule.

Credit shall be classified as problematic or commonly referred to as Non Performing Loan (NPL) if it has entered into substandard collectibility, doubtful and Non-Performing.

Sub-standard, doubtful and Non-performing loans are included in the Non-Performing Loans group that can disrupt the Bank's performance and if it occurs in large numbers it can cripple the Bank's operational activities. That is why the Bank greatly avoids the occurrence of these three collectibilities from the debtor.

\section{How to Avoid Non-Performing Loans}

Non-performing loans can occur due to internal and external factors. Bank internal factors can be:

1. Careless:

There is a lack of care (negligence) on the part of the Bank in analyzing and fulfilling all kinds of requirements of credit applications by the Debtor. This lack of attention can occur because it is driven by a desire to expand excessive activities or driven by competition between the Bank. These impulses give rise to policies that provide various leniency in meeting the requirements of lending that can cause problems in the future.

\section{Feasibility of the Work System:}

No staff and a proper work system and are able to take credit lending decisions, which basically must be done carefully by people who have sufficient ability and experience. So the decision on granting credit is not based on good analysis and in turn can lead to problem loans..

\section{Management Weaknesses:}

Management and supervision are weak from the leadership to the staff who work in the credit department, so they have freedom and therefore become less careful in making decisions about granting credit to debtors.

\section{Professionality:}

Credit distribution to relatives, friends and close people, so there is a feeling of esitation that raises the lack of caution in analyzing all the conditions that should be fulfilled in granting credit. One of the things that is difficult to be avoided by banks is to work together and/ orprovide credit to affiliated parties. According to Article 1 number 22 of Act No. 10 Year 1998, affiliated parties include:

members of the Board of Commissioners, supervisors, Directors or proxies, officers, or bank employees;

members of the management, supervisors, managers or proxies, officials, or bank employees, especially for banks that are in the form of cooperative law in accordance with applicable laws and regulations;

parties providing services to banks, including public accountants, appraisers, legal consultants and other consultants;

parties which in the opinion of The Central Bank of Indonesia have participated in influencing bank 
management, including shareholders and their families, Commissioners' families, supervisory families, Directors' families, management families;

5. Sensitive to business risks:

Less sensitive and do not have the ability to detect the risk of debtor business. The high risk of debtor business can also trigger the occurrence of problem loans.

All of the factors mentioned above must be considered carefully by the Bank to avoid nonperforming loans, because if one of the five factors is ignored, then the emergence of credit is simply a matter of time.

Avoiding problems loans early is something that must be done by the Bank. This can be obtained by carrying out Principle of $6 \mathrm{C}$ which is well known in the banking world, including:

Character, is the character of the customer, both in his personal life and in the business environment. The purpose of this character assessment is to find out the extent of the customer's willingness to fulfill their obligations (willingness to pay) in accordance with the agreed agreement.

As a tool to get a picture of the character of the prospective customer, can be achieved through efforts including::

Examining the curriculum vitae (biography) of prospective customers;;

Examining the reputation of the prospective customer in his business environment;

Request bank to bank information (Debtor Information System);

Looking for information to business associations where prospective customers are located;

Looking for information on whether prospective customers like to gamble;

Looking for information on whether prospective customers have a habbit of spreeing

2. Capasity, is the ability of prospective customers to run their business in order to obtain the expected profit. The purpose of this assessment is to find out to what extent the prospective customer is able to repay or pay off his debts in a timely manner from the business he gets.

The measurement of capacity can be carried out through the following approaches:

Historical approach, which is assessing past performance, does it show developments over time.

Financial approach, which is assessing the educational background of the board.

Juridical approach, which is legally whether the prospective customer has the capacity to represent the business entity he represents to enter into a credit agreement with the bank.

Managerial approach, which is assessing the extent to which the ability and skills of customers carry out management functions in leading the company.

Technical approach, which is to assess the extent to which the ability of prospective customers to manage factors of production such as labor, sources of raw materials, equipment, administration and finance, industrial relations to the ability to seize the market.

3. Capital, is the amount of funds/owner's equity owned by prospective customers. The greater the equity capital in the company, of course the higher the seriousness of prospective customers in running their business and the bank will feel more confident in providing credit. Owner's equity is also required by Banks as a means of seriousness and responsibility of customers in conducting their business because they bear the risk of failure of the business. In practice, this capital capability is manifested in the form of an obligation to provide self-financing, which should be greater than the amount of credit requested from the bank.

4. Colleteral, are goods surrendered by the customer as collateral for the credit received. The collateral must be assessed by the bank to determine the extent of the risk of the customer's financial obligations to the bank. In essence the collateral form is not only material but also intangible collateral such as personal guarantees (borgtocht), letters of guarantee, letters of comfort, recommendations from avalis.

5. Condition of Economi, that is, political, social, economic, and cultural situations and conditions 
that influence the state of the economy at a time which is likely to affect the smoothness of the prospective debtor company. To get a picture of this, research needs to be conducted on matters including:

a. State of conjuncture,

b. Government regulations,

c. World political and economic situation,

d. Other circumstances that affect marketing.

6. Constraint, is a limitation and obstacle that does not allow a business to be carried out at a certain place, for example the establishment of a gas station business in the vicinity of which many welding shops or brick kilns.

All of the above must be done by the Bank to avoid the possibility of non-performing loans, one of the six things above is not implemented, so the emergence of non-performing loans is just a matter of time.

\section{Solving Non-Performing Loans}

The journey of life is difficult to predict, even though someone has been careful in carrying out his life, but one time a person may encounter problems. Likewise with credit, even though the Bank has conducted careful and thorough research on prospective debtors and the Bank itself is a healthy bank, but there must have been a problem credit.

With respect to this credit problems, appropriate action needs to be undertaken by the Bank to resolve it. Actions that can be taken by banks to settle problem loans can be in the form of preventive and repressive actions.

\section{Preventive Action}

Preventive actions are activities and actions that must be carried out by the Bank before the emergence of problem loans. Some of these preventive actions have been described in chapter III above, but that is not enough. Preventive action must also be taken when a credit agreement is made.

Credit agreement is done by making a credit agreement and guarantee agreement. The credit agreement is an agreement between the Bank as the creditor and the customer as the debtor which is an individual agreement, while the collateral agreement is an agreement between the Bank as the collateral holder and the debtor or other third party as the collateral which is the material agreement.

Both the credit agreement and the guarantee agreement must be made properly and correctly in accordance with the provisions of Article 1320 of the Civil Code which determines the legal conditions of an agreement, namely:

For the validity of an agreement four conditions are required:

1. Agree for those who make an agreement;

2. The ability to make an engagement;

3. A certain thing;

4. A permissible cause

The agreement must arise from the parties making the agreement, there is no force between them or from other parties, because if there is force then the agreement can be canceled (Articles 1323, 1324 and 1325 of the Indonesian Civil Code).

Skills related to age and mentality of the parties who made the agreement. Regarding this skill, it is regulated in Article 1330 of the Indonesian Civil Code, as follows:

Not capable of making an agreement is:

People who are not yet mature;

Those who are put under authority;

Women, in matters stipulated by law, and in general everyone to whom the law has prohibited from 
making certain agreements.

Adult in the sense of the Civil Code is 21 years old or has been married before, whereas according to Act No. 1 of 1974 concerning Marriage as amended by Act Number 16 of 2019, an adult is a person who is 19 years old, another according to the Act N0. 30 of 2004 concerning Notary Position, an adult is a person who is 18 years old or has been married before..

Which maturity will be used by the Bank in making credit agreements with debtors, it depends on the form of credit agreement to be made. If the credit agreement is underhanded, the maturity provisions stipulated in the Civil Code should be used, if in the notary form, the maturity regulated in the Notary Office law is used. Thus based on the legal principle of the lex specialist de rogat legi generalis (more specific provisions rule out more general provisions).

Put under the ability are people who are insane (crazy), alchoholic, wasteful and the like, those who are not able to protect their property.

Concerning women, they can now take legal action, except those that do not meet paragraphs 1 and 2. Regarding a particular matter related to the object of the agreement, namely regarding lending. In the contents of the agreement, a minimum must be stated regarding the loan amount, term, amount of interest, method of payment, fees, fines, and guarantees. If the agreement does not include the object, then the agreement will be revoked.

Regarding a permissible cause is regarding the reason for making an agreement. An agreement is forbidden to be made if he violates the law, for example making an agreement about buying and selling people, buying and selling drugs, likewise in a credit agreement made by the Bank turns out to be interest rates that exceed the provisions set by the government. If the agreement contains such matters, including pledging to cause something to cause trouble in the community, then the agreement will be null and void.

In the event that an agreement including a credit agreement and guarantee agreement violates the provisions of paragraphs 1 and 2 of Article 1320 of the Indonesian Criminal Code, the agreement can be revoked, whereas if it breaks the provisions of paragraphs 3 and 4 of the Indonesian Criminal Code, the agreement becomes null and void.

As explained above, a credit agreement is an individual agreement, meaning that the credit agreement is only binding on those who make it and all their heirs. The point is that the right of claim held by the Bank to the debtor may only be billed to the debitor and if the debtor has passed away, it can also be collected from all heirs, but cannot be billed to other parties.

Unlike the guarantee agreement which is a material agreement. The material agreement binds anyone who controls the collateral object even if the person concerned does not participate in making the agreement as referred to in the droit de suite principle (Djumhana, 2012).

\section{Represive Action}

Repressive actions are activities and actions that must be carried out by the Bank after the emergence of problem loans, which can be done in the following ways:

\section{Through administrative means}

Based on Bank Indonesia Circular Number 25/12 / BPPP dated February 28, 1991, several policies were determined in saving Non-Performing Loans, namely:

Through Rescheduling, which is re-scheduling by making changes to several credit agreement terms, for example the extended payment term so that the balance becomes smaller.

Through reconditioning, which is to make alternation to some or all of the terms of the agreement that are not limited to changes in installment schedules or time periods, but these changes without providing additional credit.

Through restructuring, which is an effort in the form of alternating the terms of the credit agreement in the form of granting additional credit, or converting all or part of the credit, which is carried out with or without rescheduling and / or reconditioning. Based on the Decree of the Board of Managing Directors of Bank Indonesia Number 31/150 / KEP / DIR / 1998, this restructuring effort can be carried 
out through reducing interest rates, reducing interest arrears, reducing principal arrears, extending the term, adding credit facilities, taking over the assets of the assets in accordance with the provisions applicable.

\section{Through foreclosed collateral}

Foreclosed collateral hereinafter referred to in Indonesian as AYDA according to Article 1 number 15 of The Central Bank of Indonesia Regulation No.14/15/2012, are as follows::

Foreclosed collateral hereinafter referred to in Indonesian as AYDA is an asset obtained by a bank, either through an auction or outside the auction based on voluntary surrender by the collateral owner, or based on the power to sell outside the auction from the collateral owner in the event that the debtor does not fulfill his obligations to the bank.

Foreclosed collateral in this case are based on voluntary surrender by the collateral owner. So the collateral owner (in this case the collateral or collateral in the form of land and / or building) voluntarily surrenders the collateral to the Bank and for this reason an agreement is made in an authentic (notary) form before a Notary Public which is not a sale and purchase agreement followed by a Power of Attorney for sell.

The usefulness of the voluntary surrender agreement in the form of Foreclosed Collateral (referred as AYDA in Indonesian) which is followed by the Power of Attorney to sell in this case is therefore the bank can sell the collateral (land) as soon as possible and the proceeds of the sale are used to pay off debtors' debts.

\section{Through arbitration}

Arbitration institutions have long been known in the legal domain in Indonesia, namely in Act Number 14 of 1970 concerning the Principal Provisions of Judicial Power, as well as in practice have been recognized by the arbitral institution, as evidenced in several decisions of the Supreme Court of the Republic of Indonesia, namely:

1) Nomor Number 225 K / Sip / 1976 dated 30 September 1983 which recognized the arbitration clause as valid as the law;

2) Number 3992 K / Sip / 1984 dated May 4, 1988 which confirms that the authority to examine a dispute arising from an agreement that contains an absolute arbitration clause becomes the authority of the arbitration institution, and is further strengthened by the decision number $3179 \mathrm{~K} / \mathrm{Pdt} / 1984$ on May 4 1988, which confirmed that the District Court was not authorized to examine arbitration suits in conventions or reconventions (Asikin, 2016).

The advantages of using an arbitral institution include: faster settlement, the decision can be agreed, is the first and last decision, can not be requested for cassation or reconsideration, the parties to the dispute can appoint an arbitrator, terminated in a closed door so as to avoid publication, how to execute like a court ruling that has been incracht.

\section{Through Litigation Process in Court}

The litigation process by filing a lawsuit in court is a forced and final step taken by the Bank against bad credit, because the court process is considered too long and long-winded by some people. While on the other hand the Bank is very concerned to resolve the problem of bad loans.

Court decisions that have been incracht must be implemented by litigants, so if the Bank wins the lawsuit, the Bank can execute the disputed guarantee.

\section{CONCLUSION}

Based on the description above, it turns out that non-performing loans can be in the form of substandard, doubtful or bad loans called collectibility which can disrupt the Bank's performance and if it occurs in large amounts it can weaken the Bank's operational activities. That is why the Bank greatly avoids the occurrence of these three collectibilities from the debtor.

It turns out that problem loans can occur from internal and external factors of the bank, to avoid problem loans from internal factors can be done by increasing accuracy, increasing the feasibility of the work system, improving management performance so that management is not weak, prioritizing 
professionalism and having sensitivity to business risk. From external factors can be overcome by using the principle of $6 \mathrm{C}$, which assess: 1) Charecter or prospective psychiatric atmosphere, 2) Capasity, namely the ability of prospective customers to carry out their obligations, 3) Capital, namely the capital participation of prospective customers in their business, 4) Collateral namely collateral used by prospective customers, 5) Conditions of Economics are social, political, economic and cultural situations that can affect the economy, and 6) Constraint is the limits and obstacles that may occur and can affect the ability of customers in carrying out their obligations.

If the principle $6 \mathrm{C}$ has been carried out but apparently there are also problem loans, there are two ways to solve them, namely repressive and preventive actions. Repressive actions can be carried out by making credit agreements and guarantee agreements in the authentic form and following the existing laws and regulations, whereas preventive actions can be done through: 1) administrative methods, namely credit restructuring, 2) through foreclosed collateral (referred as ADYA in Indonesia), 3) through arbitration, and 4) through litigation in court.

\section{References}

Act. No. 14 Year 1970 concerming Basic Provisions of Judicial Power.

Act No. 1 Year 1974 concerning marriage as amended by Act No. 16 Year 2019.

Act No.10 Year 1998 concerning amendment of Act No.7 Year 1992 Concerning Banking.

Act No. 30 Year 2004 concerning Notary Position.

American Bankers Association (1971). Principle of Bank Operation, USA: American Institute of Banking.

Asikin, H. Z. (2016). Pengantar Hukum Perbankan Indonesia. Jakarta: PT Raja Grafindo Persada.

Civil Code of Republic of Indonesia.

Departemen Of National Eduation. (2014). Kamus Besar Bahasa Indonesia. Jakarta: PT. Gramedia Pustaka Utama.

Djumhana, M. (2012). Hukum Perbankan di Indonesia. Bandung: PT. Citra Aditya Bakti.

https://arsasi.wordpress.com/2008/09/21/analisa-kredit-6c/

Mahmoeddin, A. (2004). Melacak Kredit Bermasalah. Jakarta: Pustaka Sinar Harapan.

Simorangkir, O. P. (1989). Kamus Perbankan, Cetakan ke-2. Jakarta: Bina Aksara.

The Regulation of The Central bank of Indonesia No. 14/15/2012.

The Decree of Directors of The Central Bank of Indonesia No. 31/147/KEP/DIR dated 12 of November 1998 concerning Quality of Productive Assest 